\title{
PREFERENSI KONSUMEN TERHADAP TRANSPORTASI PUBLIK (STUDI KASUS BUS RAPID TRANSIT (BRT) KOTA SEMARANG)
}

\author{
Ichwinsyah Azali \\ Email : ichwinsyah.azali@gmail.com \\ Edy Yusuf Agung Gunanto \\ Email: edy.yusuf.ag@gmail.com \\ Nugroho SBM \\ Departemen IESP Fakultas Ekonomika dan Bisnis Universitas Diponegoro \\ Email:nugroho.sbm@gmail.com
}

\begin{abstract}
Abstrak
Kota Semarang sebagai ibukota Provinsi Jawa Tengah memiliki tingkat kepadatan penduduk sebesar $4.269 \mathrm{jiwa} / \mathrm{km} 2$ pada tahun 2015. Dengan tingkat kepadatan yang cukup tinggi, mobilitas yang terjadi akan terus meningkat. Pemerintah mengatur kebijakan Lalu Lintas dan Angkutan Jalan melalui Undang-Undang Nomor 22 Tahun 2009 pasal 158 ayat 1, pemerintah kota Semarang menyediakan kebutuhan angkutan massal di kawasan perkotaan berupa Bus Rapid Transit (BRT) Trans Semarang. Penelitian ini bertujuan untuk menganalisis preferensi konsumen dari segi harga, kenyamanan, keandalan, aksesibilitas, dan keamanan terhadap kemungkinan pemilihan moda BRT dan moda transportasi Non-BRT. Penelitian ini menggunakan 100 responden dengan purposive sampling. Model Binary Logistic Regression digunakan untuk mengetahui pengaruh variabel independen terhadap variabel dependen pemilihan moda BRT dan Non-BRT. Hasil penelitian menunjukkan bahwa pemilihan moda BRT dan Non-BRT di Kota Semarang didominasi oleh pengguna 82 responden untuk BRT dan 18 responden untuk Non-BRT. Pemilihan moda BRT dan Non-BRT dipengaruhi oleh harga, faktor kenyamanan, keandalan, aksesibilitas dan keamanan.

Kata Kunci: Pemilihan Moda, Bus Rapid Transit (BRT) Trans Semarang, Binary Logistic Regression.
\end{abstract}

\begin{abstract}
Semarang as the capital city of Central Java Province has a population density of 4.269 per square kilometer in 2015. Due to high population density, communities' mobility will also be increasing. Government arranged the policy related to traffic and public transportation in the Law Number 22 Year 2009 article 158 paragraph 1, the government of Semarang City has guaranteed the availability of road-based transportation in Urban Areas by providing public transportation namely Bus Rapid Transit (BRT) Trans Semarang. This research aims to analyze communities' preference in terms of price, convenience, reliability, accessibility, and safety toward the possibility of BRT and Non BRT transportation modes selection. This research uses 100 respondents by Purposive Sampling. Binary Logistic Regression model is applied to determine the effect of independent variable towards
\end{abstract}


dependent variable of BRT and Non BRT transportation modes selection. The result of this research indicated that BRT and Non BRT transportation modes selection in Semarang City are dominated by 82 respondents of BRT users and 18 respondents of Non BRT users. BRT and Non BRT transportation modes selection are affected by the factor of price, convenience, reliability, accessibility, and safety.

Keywords: Modes selection, Bus Rapid Transit (BRT) Trans Semarang, Principal Component Analysis, Binary Logistic Regression.

\section{PENDAHULUAN}

Kota Semarang merupakan Ibukota Jawa Tengah dengan luas wilayah $373.70 \mathrm{~km}^{2}$ dan jumlah penduduk sebesar 1.595.267 jiwa memiliki tingkat kepadatan penduduk sebesar 4269 jiwa $/ \mathrm{Km}^{2}$. Adanya Kepadatan Penduduk dan pertumbuhan penduduk, mengakibatkan meningkatnya arus mobilitas penduduk (Martini dan Sudibia, 2013).

Mobilitas penduduk yang meningkat seharusnya diimbangi dengan infratrusktur yang memadai. Namun pada kenyataannya tidak ada perubahan atau penambahan panjang dan sarana transportasi publik masih belum memadai. Sehingga penduduk lebih memilih jenis kendaraan pribadi dengan jumlah kendaraan bermotor pada tahun 2015 sebesar 190.107, dengan jumlah kendaraan pribadi yang terus bertambah dan tidak diimbangi dengan infrastruktur yang memadai dapat menimbulkan permasalahan transportasi yang salah satunya ialah kemacetan. Menurut Jou dan Chen (2014) banyaknya penggunaan kendaraan pribadi tidak hanya menyebabkan kemacetan lalu lintas dan waktu perjalanan lebih tetapi juga pencemaran lingkungan, dan memberikan kontribusi untuk masalah yang terkait dengan konsumsi energi.

Perencanaan sistem transportasi yang baik diperlukan dalam mengatasi permasalahan kemacetan. Pembenahan jalan, rambu- rambu jalan, serta pengadaan transportasi massal yang baik harus direncanakan dengan matang (Putra, 2013). Sistem transportasi massal menjadi salah satu solusi dalam mengurangi kemacetan. Menurut Susantono et.al (dalam aminuddin, 2008) Sistem Transportasi massal yang baik akan mengurangi kebutuhan dan keinginan untuk mempunyai kendaraan pribadi dan berdampak pada berkurangnya jumlah kendaraan bermotor.

Menurut Undang-Undang Republik Indonesia Nomor 22 Tahun 2009 tentang Lalu Lintas dan Angkutan Jalan Pasal 158 Ayat (1) "Pemerintah menjamin ketersediaan Angkutan Massal berbasis jalan untuk memenuhi kebutuhan angkutan orang kendaraan umum di kawasan perkotaan". Kota Semarang sendiri memiliki berbagai jenis angkutan umum massal seperti bus atau mobil angkutan umum yang dikelola oleh pihak swasta maupun pemerintah daerah. Dalam Masterplan Transportasi Kota Semarang 2009-2029 menjelaskan masih belum terpenuhinya jumlah kendaraan umum berupa bus atau angkutan umum di trayek utama, cabang dan ranting, serta kualitas pelayanan angkutan umum masih dikategorikan rendah.

Pada tahun 2010 Pemerintah Kota semarang telah menyediakan jenis tranportasi massal berupa Bus Rapid Transit atau yang dikenal sebagai BRT Trans Semarang. BRT menggunakan sistem yang baru yang diharapkan dapat memberikan kualitas pelayanan yang lebih baik daripada alat angkutan umum 
lainya yang sudah ada. Diharapkan dengan pelayanan yang lebih baik dapat menarik minat masyarakat untuk beralih menggunakan alat transportasi umum dan mengurangi penggunaan alat transportasi pribadi.

BRT masih memiliki kualitas pelayanannya masih rendah. Sebagian besar penumpang BRT Trans Semarang mengeluh mengenai jumlah tempat duduk tidak sesuai dengan jumlah penumpang, halte yang kurang bersih, kurang terawat, dan kurang teduh, serta lamanya waktu menunggu bus (Prasurvey). Keluhan lainnya ialah belum tersedia papan informasi mengenai kedatangan BRT, kurangnya perhatian bagi calon penumpang penyandang cacat, ibu hamil, lansia untuk menggunakan BRT, dan sistem tiket yang masih berjalan secara manual atau ditarik oleh petugas (Trinandika, et al., 2013).

Penelitian sebelumnya yang dilakukan oleh Wiji pada tahun 2009 tentang pengaruh status sosial ekonomi terhadap pemilihan moda transportasi untuk perjalanan kerja dengan menggunakan variabel dependen pemilihan moda (moda pribadi, angkutan umum, jalan kaki) dan untuk variabel independennya adalah biaya perjalanan waktu perjalanan, aksesibilitas/kemudahan, kepemilikan moda, status sosial ekonomi, struktur rumah tangga, dan kenyamanan disimpulakn bahwa mayoritas pekerja menggunakan moda pribadi untuk perjalanan kerjanya, faktor sosial ekonomi seperti jabatan, penghasilan dan pendidikan berpengaruh terhadap pemilihan moda, dan faktor selain sosial ekonomi seperti biaya perjalanan, kepemilikan kendaraan, waktu dan jarak turut mempengaruhi pemilihan moda.

Pada penelitian yang dilakukan oleh Ludfi Djakfar, dkk (2010) mengenai studi karakteristik dan model pemilihan moda angkutan mahasiswa menuju kampus (sepeda motor atau angkutan umum) di Kota Malang menyatakan bahwa uang saku, jenis kelamin, kepemilikan SIM, lama perjalanan dari rumah ke kampus, ketersediaan angkutan, nyaman dan cocok, waktu perjalanan memiliki pengaruh yang signifikan terhadap pemilihan moda transportasi menuju kampus

Permasalahan kualiatas pelayanan transportasi umum di Kota Semarang berupa transportasi BRT maupun NonBRT menjadi suatu hal yang perlu diperhatikan pemerintah kota agar sarana transportasi umum yang di sediakan menjadi salah satu solusi dalam permasalahan transportasi yang ada.

\section{LANDASAN TEORI \\ Permintaan dalam ekonomi trans- portasi}

Nasution (2004) mengatakan kebutuhan akan transportasi tidak sama seperti halnya dengan kebutuhan pangan dan sandang, karena kepuasan akan kebutuhan sandang dan papan dapat dirasakan langsung, sedangkan pemuasan kebutuhan transportasi yang diciptakan sebagai akibat penggunaan jasa transportasi. Permintaan jasa transportasi akan terjadi apabila antara dua atau lebih terdapat perbedaan kegunaan marjinal terhadap sesuatu barang, yang satu tinggi dan yang lain rendah. Sebagai contoh arus barang, barang akan berpindah dari tempat yang kegunaan marjinal terhadap sesuatu barang rendah ke tempat di mana kegunaan marjinal dari barang tersebut tinggi.

Permintaan jasa transportasi terdapat beberapa sifat khusus yang membedakannya dengan permintaan terhadap barang-barang lain, antara lain:

1. Derived demand. Permintaan jasa transportasi merupakan suatu permintaan yang bersifat turunan. Permintaan jasa transportasi baru akan timbul apabila ada hal-hal dibalik permintaan itu, misalnya 
keinginan untuk rekreasi, sekolah, berbelanja, dan sebagainya.

2. Permintaan akan jasa transportasi pada dasarnya adalah seketika atau tidak mudah untuk digeser atau ditunda dan sangat dipengaruhi oleh fluktuasi waktu yang bersifat harian, mingguan, bulanan atau tahunan.

3. Sangat dipengaruhi oleh elastisitas pendapatan.

4. Pada hakikatnya tidak dianggap atau perasa terhadap perbedaan tingkat biaya transpor untuk pengangkutan penumpang, tetapi sangat perasa atau tanggap terhadap pengangkutan barang

5. Jasa transportasi adalah jasa campuran. Permintaan akan jasa transportasi adalah kompleks, karena permintaan tersebut tidak hanya dilandasi oleh keinginan untuk memindahkan sesuatu dari suatu tempat ke tempat lain, tetapi banyak variable-variabel lain yang mempengaruhi keinginan untuk memindahkan barang tersebut.

Cole (2005) berpendapat bahwa transportasi adalah layanan yang bersifat tidak biasa dalam permintaan dan memiliki karakteristik tersendiri. Pemintaan akan transportasi dikatakan sebagai derived demand yang artinya permintaan akan terjadi karena ada faktor-faktor yang mendorongnya, misalnya sebuah perusahaan yang memproduksi barang seperti pakaian atau makanan melihat transportasi sebagai sarana distribusi produknya dari pabrik atau gudang ke toko ritel. Apabila permintaan akan barang tersebut meningkat, permintaan akan transportasi juga akan meningkat.

Cole (2005), ada beberapa faktor dalam menentukan permintaan akan transportasi, antara lain:

1. Karakteristik fisik

Dalam kasus komoditas, pemilihan moda tergantung pada karakteristik fisik barang. Apabila barang yang bernilai tinggi dan jumlah muatan barang yang sedikit, biasanya menggunakan jalur udara. Barang yang bernilai rendah dan jumlah muatan barang besar biasanya menggunakan jalur darat dan laut.

2. Harga

Rendahnya harga transportasi membuat semakin banyak orang cenderung untuk menuntut layanan transportasi yang ditawarkan.

3. Harga relatif yang dikenakan dari moda dan operator yang berbeda

Transfer bisnis ini antara moda atau perusahaan di angkutan penumpang ditentukan untuk sebagian besar oleh tingkat relatif dari tarif pada layanan kereta api, kapal, bus dan layanan udara, dan biaya yang dirasakan dari mobil travel (yaitu harga bensin dan biaya parkir).

4. Pendapatan penumpang

Apabila pendapatan yang dimiliki meningkat, jumlah perjalanan baik untuk bisnis dan liburan (baik dari perjalanan atau jumlah jarak).

5. Kecepatan layanan

Faktor waktu menjadi pertimbangan pemilihan moda transportasi oleh penumpang. Bagi mereka yang mempunyai waktu sedikit biasanya mencari atau memilih moda transportasi yang cepat, jadi faktor kecepatan yang menentukan pemilihan moda transpor dan begitu pun sebaliknya.

6. Kualitas pelayanan

a. Frekuensi

Tingginya frekuensi keberangkatan dan kedatangan dari suatu moda transportasi, membuat pemakai jasa transportasi mempunyai banyak pilihan.

b. Pelayanan baku

Suatu moda transportasi yang dapat memberikan pelayanan yang baku dan dilaksanakan secara konsisten sangat disenangi oleh para pemakai jasa transportasi. Kualitas layanan 
yang disediakan telah menjadi strategi pemasaran utama, sebagai contoh ketepatan jadwal keberangkatan dan kedatangan, fasilitas untuk menunggu, dan lain sebagainya.

c. Kenyamanan

Dalam milenium baru standar hidup mayoritas harus tercermin oleh operator penumpang jika mereka ingin terus menarik permintaan untuk layanan mereka.

d. Ketepatan

Alasan yang sering hilangnya langganan tetap oleh kedua operator angkutan penumpang dan barang terletak pada kegagalan untuk mengirimkan barang tepat waktu atau untuk mendapatkan penumpang ke tujuan mereka atau ke layanan yang menghubungkan pada waktu yang dijadwalkan.

e. Keamanan

Ini selalu menjadi perhatian penumpang, otoritas pemerintah dan sebagian besar operator. Kecelakaan pada suatu moda transportasi akan mengurangi permintaan moda tersebut, terutama dalam jangka pendek.

\section{Penelitian Terdahulu}

Penelitian Aidoo et al. (2013) meneliti mengenai kepuasan penumpang terhadap pelayanan angkutan umum di Ghana. Metode yang digunakan yaitu dengan regresi logistik. Variabel dependen dari penelitian ini adalah nilai baik atau tidak baik yang merepresentasikan penilaian penumpang terhadap layanan angkutan umum bus. Variabel independen yang digunakan yaitu struktur tarif, tingkat kejahatan di bus, keselamatan lalu linta, kebersihan bus, status responden, kesesuaian dengan pengguna dan kenyamanan kursi. Jumlah responden yang digunakan dalam penelitian ini sebanya 492 responden. Hasil dari estimasi regresi logistik menemukan bahwa $90 \%$ penumpang puas dengan pelayanan struktur tarif (OR $=1.897 ; \mathrm{p}=0,026)$. Indikator kebersihan bus secara menyeluruh tidak signifikan $(\mathrm{OR}=1.379 ; \mathrm{p}=0.324)$. Indikator ketersediaan kursi yang nyaman di bus memiliki hasil yang signifikan $(\mathrm{OR}=$ 1.888; $\mathrm{p}=0.065)$. Indikator kesesuaian penggunaan signifikan terhadap preferensi konsumen terhadap penilaian pelayanan bus (OR $=1.765 ; \mathrm{p}=0.073)$. Hasil dari Indikator keamanan di dalam bus yaitu signifikan $(\mathrm{OR}=1.829$; $\mathrm{p}=0.033$ ). Indikator lalu lintas bus, memiliki hasil yang siginifkan $(\mathrm{OR}=$ 4,407; $\mathrm{p}<0,001)$.

Penelitian Ismail et al (2012) mengindentifikasi mengenai kepuasan konsumen terhadap layanan transportasi di Malaysia. Responden yang diteliti dalam penelitian ini adalah penduduk berusia 15 - 60 tahun dengan total responden sebanyak 616 respondent di negara bagian Selangor dan Kuala Lumpur yang pernah menggunakan transportasi umum bus. Metode analisis yang digunakan yaitu analisis korelasi antara variabel, analisis faktor untuk mengelompokkan variabel dan analisis regresi. Variabel dependen yag digunakan dalam penelitian ini yaitu preferensi konsumen terhadap transportasi publik bus. variabel independen yang digunakan dalam penelitian ini yaitu frekuensi keberangkatan bus, waktu tunggu, tarif, perilaku driver, ketepatan waktu, ketersediaan kursi, fasilitas di dalam bus, bagasi kebersihan, informasi wisata dan fasilitas untuk penyandang disabilitas. Hasil penelitian yaitu: 1) hasil dari KMO and Bartlett's test analysis menunjukan bahwa variabel-variabel yang mempengaruhi referensi seseorang memilih menggunakan transportasi bus 
bisa dianalisislebih lanjut. Nilai KMO lebih dari 0,5 dan nilai Bartlett's Test of Sphericity yang signifikan dengan nilai $\mathrm{p}$ $<0,005$. analisis korelasi yang dilkukan dalam penelitian ini menunjukan bahwa variabel frekuensi bus, kenyamanan dalam perjalanan, keamanan dan informasi wisata memiliki koreasi. 2) hasil dari Principal Component Analysis / PCA menunjukan ada tiga komponen utama yang bisa digunakan untuk yaitu Fasilitas, kenyamanan, dan pelayanan. Masing-masing mendapatkan nilai Eigen sebesar 3.758 ; 2.990 dan 1.990. 3) Hasil dari analisis regresi menunjukan bahwa ada pengaruh yang sigfinikan ( nilai $\mathrm{F}$ test dengan nilai $\mathrm{p}<0,005)$ dari tiga variabel independen (Fasilitas, kenyamanan, dan pelayanan) terhadap variabel dependen tentang preferensi konsumen terhadap penggunaan bus. Nilai $\mathrm{R}^{2}$ dalam regresi sebesar $8,47 \%$. Hal ini menunjukan bahwa 84,7 \% variabel independen dapat menjelaskan mengenai keputusan atau preferensi seseorang dalam memilih penggunaan transportasi publik di Malaysia.

\section{METODE PENELITIAN}

Analisis preferensi konsumen dengan menggunakan regresi logistik dalam peneltian ini menggunakan dua variabel yaitu variabel dependen atau variabel terikat dan variabel indpenden atau variabel bebas.

Variabel dependen dalam penelitian ini yaitu pemilhan moda transportasi umum Bus Rapid Transit (BRT) Trans Semarang dan transportasi umum non BRT (Bus Kota dan Angkutan Kota ). variabel indepanden yang digunakan dalam penelitian ini adalah pemilihan moda transportasi, harga transportasi umum, kenyamanan transportasi umum, keandalan transportasi umum, aksesbilitas transportasi umum dan keamanan transportasi umum. Sampling atau metode yang digunakan dalam pengambilan sampel dalam penelitian ini adalah Purposive Sampling. Penentuan sampel menggunakan teknik Purposive Sampling harus dilakukan dengan menggunakan kriteria-kriteria terhadap responden. Kriteria-kriteria tersebut yaitu:

1. Responden merupakan warga kota Semarang

2. Responden yang pernah menggunakan angkutan umum di Kota Semarang, baik angkutan umum BRT maupun non BRT.

Berdasarkan data jumlah penduduk Kota Semarang di Kota Semarang pada tahun 2016. Jumlah pengguna transportasi umum di Kota Semarang sebesar 8.023.869, sehingga jumlah sampel berdasarkan perhitungan dengan pendekatan Slovin sebesar 99, 99 atau dibulatkan menjadi 100 mengggunakan nilai toleransi sebesar $10 \%)$.

Metode analisis yang digunakan dalam penelitian ialah analisis komponen utama atau Principal Component Analysis dan analisis regresi logistik. Analisis komponen utama atau Principal Component Analysis adalah suatu teknik analisis secara statistik untuk mengubah bentuk asli dari sekumpulan variabel asli secara linear menjadi sekumpulan variabel yang lebih kecil yang tidak berkorelasi, sehingga dapat mewakili variabel asli.

Tujuan dari PCA untuk menjelaskan variasi dalam kumpulan variabel yang diamati berdasarkan beberap dimensi. Secara sederhana analisis komponen utama atau principal component analysis menyederhakan banyak variabel menjadi lebih sedikit variabel. Tujuan secara khusus analisis PCA yaitu, 1) meringkas korelasi antar variabel yang di observasi, 2) menyederhanakan variabel dengan jumlah besar menjadi beberapa faktor 
kecil, 3) memberikan sebuah definisi operasional dimesnsi pokok penggunaan variabel yang akan di observasi dan 4) menguji teori yag mendasari penelitian tersebut (Umar,2009). Husna (2016) menjelaskan beberapa langkah dalam Analisis Komponen Utama atau Principal Component Analysis, sebagai berikut :

1. Seleksi dan pengukuran variabel

2. Penentuan Jumlah Faktor

3. Rotasi Faktor

4. Intepretasi hasil

Menurut Gujarati (2013) Regresi Logistik atau Logistc Regression adalah model regresi dengan variabel dependen berupa variabel dikotomi atau variabel dengan nilai kualitatif. Model dalam regresi logsitik biasanya juga disebut sebagai model probabilitas. Contohnya dalam satu penelitian, variabel dikotomi yaitu berupa jawaban 1 berarti ya dan 0 berarti tidak. Penurunan model awal yaitu sebagai berikut :

$$
\begin{gathered}
P i=\beta_{1}+\beta_{2} X_{1 i}+\beta_{3} X_{2 i}+\beta_{4} X_{3 i}+\beta_{5} X_{4 i}+ \\
\beta 6 X 5 i \ldots .(\mathbf{1})
\end{gathered}
$$

$\mathrm{X}$ adalah variabel indepden yang mempengaruhi preferensi seseorang menggunakan Bus Rapid Transit ( BRT ) Trans Semarang dan $P_{i}=E\left(Y_{i}=1 \mid X_{i}\right)$ probabiitas seseorang memilih menggunakan Bus Rapid Transit ( BRT ) Trans Semarang. Persamaan 1 tidak dapat di estimasi dengan menggunakan metode regresi OLS, maka persamaan 1 disederhanakan menjadi sebagai berikut :

$$
P i=\frac{1}{1+e^{-\beta 1+\beta 2 X 1 i+\beta 3 X 2 i+\beta 4 X 3 i+\beta 5 X 4 i+\beta 6 X 5 i}}(2)
$$

Persamaan tersebut disederhakan kembali menjadi :

$$
P_{i}=\frac{1}{1+e^{-Z i}}=\frac{e^{z}}{1+e^{z}} \ldots \ldots \text { (3) }
$$

Dimana $\mathrm{Zi}=\beta_{1}+\beta_{2} X_{1 i}+\beta_{3} X_{2 i}+\beta_{4} X_{3 i}+$ $\beta_{5} X_{4 i}+\beta_{6} X_{5 i}$

Fungsi distribusi logistik (Logitic Distribution Function) diwakili oleh persamaan 3. Rentang $\mathrm{P}$ antara 0 dan 1 dan bahwa $P_{i}$ bersifat non linear terhadap $Z_{i}$, karena $Z_{i}$ memiliki rentang dari $-\infty$ hingga $+\infty$ sehingga sudah memenuhi persyaratan bahwa $\mathrm{Y}$ berada pada interval antara $0-1$.

Adanya kesalahan pada estimasi karena Pi bersifat non linear bukan hanya pada $X$, melainkan juga pada $\beta$ seperti yang dapat dilihat dengan jelas pada persamaan 2. hal ini mengindikasikan bahwa prosedur OLS tidak dapat digunakan untuk mengestimasi. Jika Pi adalah probabilitas menggunakan Bus Rapid Transit ( BRT ) Trans Semarang ditunjukan oleh persamaan 3. Probabilitas tidak menggunakan Bus Rapid Transit ( BRT ) Trans Semarang ditunjukan dengan ( $1-P i$ ), maka persamaannya sebagai berikut :

$$
1-P i=\frac{1}{1+e^{z i}}
$$

Sehingga persamaan peluangnya dapat ditulis sebagi berikut :

$$
\frac{P i}{1-P i}=\frac{1+e^{z i}}{1+e^{z i}}=e^{z i}
$$

Rasio peluang ( odd ratio ) dari seseorang konsumen menggunakan Bus Rapid Transit (BRT) Trans Semarang atau rasio probabilitas konsumen memilih menggunakan Bus Rapid Transit ( BRT ) Trans Semarang terhadap probabilitas tidak memilih menggunakan Bus Rapid Transit ( BRT ) Trans Semarang dijelaskan oleh persamaan 5 yaitu $P i / 1-$ $P i$. Logaritma natural dari persamaan 5 yaitu :

$$
\begin{aligned}
& L i=\ln \left(\frac{P i}{1-P i}\right)=Z i \\
= & \beta_{1}+\beta_{2} X_{1 i}+\beta_{3} X_{2 i}+\beta_{4} X_{3 i}+\beta_{5} X_{4 i}+\beta_{6} X_{5 i}+\beta_{7} X_{6 i} \\
\ldots & (6)
\end{aligned}
$$

Persamaan 6 menunjukan persamaan regresi logistik (Model Logit). Persamaan yang menunjukan estimasi model logit untuk mengathui peluang seorang konsumen memilih meng- 
gunakan Bus Rapid Transit ( BRT ) Trans Semarang, sebagai berikut :

$\mathrm{L}_{\mathrm{Yi}}=\operatorname{Ln}\left(\frac{P i}{1-P i}\right)=\beta_{1}+\beta_{2} X_{1 i}+\beta_{3} X_{2 i}+\beta_{4} X_{3 i}+$ $\beta_{5} X_{4 i}+\beta_{6} X_{5 i}+\mu \mathrm{i}$

$\mathrm{L}_{\mathrm{Yi}}=\operatorname{Logit} \mathrm{Y}$

$\operatorname{Ln}\left(\frac{P i}{1-P i}\right) \quad=$ Ln $\left(\frac{\text { Memilih BRT Trans Semarang }}{\text { Tidak memilih Non BRT }}\right)=$ Odd

Ratio konsumen memilih menggunakan Bus Rapid Transit (BRT) Trans Semarang yang diwakili oleh 1 dan memilih Transportasi Non Bus Rapid Transit ( BRT ) yang diwakili dengan 0 .

Dimana :

$\beta_{0} \quad=$ intercept

$X_{1} \quad=$ Harga Transportasi Umum

$X_{2} \quad=$ Kenyamanan Transportasi

Umum

$X_{3} \quad=$ Keandalan Transportasi Umum

$X_{4} \quad=$ Aksesbilitas Transportasi

Umum

$X_{5} \quad=$ Keamanan Transportasi Umum

$\mu \quad=$ Errorterm

$\beta_{123456}=$ Slope

\section{HASIL PENELITIAN}

\section{Analisis Komponen Utama (Principal Component Analysis)}

Beberapa variabel diukur dengan skala persepsi masing-masing diukur dengan menggunakan lebih dari satu pertanyaan sehingga kelima variabel tersebut terlebih dahulu diuji dengan metode Analisis Komponen Utama atau Principal Component Analysis (PCA). Pada tahap awal dengan pengujian terhadap komponen variabel menggunakan uji Measure of Sampling Adequancy (MSA), Keiser Meyer-Olkin (KMO) dan Barlett's Test of Sphericity. Uji reliabilitas digunakan untuk menguji sejauh mana keandalan suatu alat pengukur untuk dapat digunakan lagi untuk penelitian yang sama. Pengujian reliabilitas dalam penelitian ini adalah dengan menggunakan rumus Alpha. Pengujian validitas dan selengkapnya dapat dilihat pada Tabel 1:

Tabel 1. Hasil Analisis Komponen Utama

\begin{tabular}{llr}
\hline \multicolumn{3}{c}{ KMO and Bartlett's Test } \\
\hline \multicolumn{2}{l}{ Kaiser-Meyer-Olkin Measure of } \\
Sampling Adequacy. & .844 \\
Bartlett's Test of & Approx. & 1458.971 \\
Sphericity & Chi-Square & 253 \\
& Df & .000 \\
\hline
\end{tabular}

Sumber: Data primer yang diolah 2017

Tabel 1 menunjukkan nilai KMO sebesar 0,844. Nilai KMO tersebut lebih besar dari 0,50 yang memenuhi tingkat penerimaan analisis. Selain itu nilai Bartlett Chi square sebesar 1468,971 dengan signifikansi sebesar $0,000(<0,05)$, yang menunjukkan bahwa hasil analisis faktor sudah melakukan reduksi faktor dengan baik dengan membentuk 5 faktor baru.

Hasil ekstraksi faktor mendapatkan bahwa semua nilai loading factor memiliki nilai di atas 0,50 yang menunjukkan berada pada faktor yang diterima. Selain itu faktor-faktor hasil rotasi mengelompok pada faktor yang bersesuaian yang menunjukkan bahwa hasil analisis faktor menunjukkan bahwa indikator-indiktor pada kelima variabel tersebut memiliki validitas konvergen dan validitas diskriminan yang baik dalam mengukur masing-masing variabel.

Tabel 2. Hasil Pengujian Reliabilitas

\begin{tabular}{clcl}
\hline No & $\begin{array}{l}\text { Variabel / } \\
\text { Indikator }\end{array}$ & $\begin{array}{c}\text { Cronbach } \\
\text { Alpha }\end{array}$ & Keterangan \\
\hline 1 & Harga & 0.838 & Reliabel \\
2 & Kenyamanan & 0.917 & Reliabel \\
3 & Keandalan & 0.882 & Reliabel \\
4 & Aksesibilitas & 0.848 & Reliabel \\
5 & Keamanan & 0.841 & Reliabel \\
\hline
\end{tabular}

Sumber: Data primer yang diolah 2017

Tabel 2 menjelaskan tentang hasil uji reliabilitas, bahwa semua variabel mempunyai koefisien alpha yang cukup besar yaitu diatas 0,60. Variabel Harga 
nilai Cronbach Alpha sebesar 0.838 dimana, nilainya lebih besar dari 0,60 yang artinya bahwa variabel harga lolos pengujian realiabilitas. Selain variabel harga ada variabel kenyamanan, keandalan, aksesibilitas dan keaman dengan nilai cronbach alpha masingmasing sebesar $0.917,0.882,0.848$, dan 0.841, diketahui dari keseluruhan variabel nilai cronbach alphanya lebih dari 0.60. Sehingga dapat dikatakan konsep pengukur masing-masing variabel dari kuesioner adalah reliabel sehingga untuk selanjutnya item-item pada masing-masing konsep variabel tersebut layak digunakan sebagai alat ukur. Analisis pengujian hipotesis penelitian dilakukan dengan menggunakan analisis regresi logistik. Berikut adalah urutan analisisnya; Pengujian kelayakan model (Model Fit), Koefisien determinasi dan Pengujian koefisien regresi.

Tabel 3. Hasil uji Hipotesis

\begin{tabular}{lrlll}
\hline \hline \multicolumn{1}{c}{ Variable } & Coefficient & Std. Error & z-Statistic & Prob. \\
\hline \hline Harga & 0.220146 & 0.113592 & 1.938039 & 0.0526 \\
Kenyamanan & 0.306392 & 0.118177 & 2.592660 & 0.0095 \\
Keandalan & 0.317170 & 0.156567 & 2.025776 & 0.0428 \\
Aksesibilitas & 0.456428 & 0.175546 & 2.600045 & 0.0093 \\
Keamanan & 0.480861 & 0.224629 & 2.140684 & 0.0323 \\
C & -28.50204 & 8.131772 & -3.505021 & 0.0005 \\
\hline \hline McFadden R-squared & 0.759851 & Mean dependent var & 0.820000 \\
S.D. dependent var & 0.386123 & S.E. of regression & 0.185750 \\
Akaike info criterion & 0.346409 & Sum squared resid & 3.243287 \\
Schwarz criterion & 0.502719 & Log likelihood & -11.32046 \\
Hannan-Quinn criter. & 0.409671 & Restr. log likelihood & -47.13935 \\
LR statistic & 71.63777 & Avg. log likelihood & -0.113205 \\
Prob(LR statistic) & 0.000000 & & \\
Sumber : SPSS (diolah) & \multicolumn{4}{l}{} \\
\hline
\end{tabular}

Analisis pertama yang dilakukan adalah menilai kelayakan model regresi logistik yang akan digunakan. Pengujian kelayakan model regresi logistik dilakukan dengan menggunakan Goodness of Fit Test yang diukur dengan nilai LR ratio (likelihood ratio). Hasil pengujian likelihood (LR ratio) mendapatkan nilai LR sebesar 71,63777 dengan signifikansi sebesar 0,000 yang berada di bawah 0,05 pada model tersebut. Hal ini mencerminkan bahwa model tersebut adalah model yang baik dalam menjelaskan pengaruh variabel harga, kenyamanan, keandaan, aksesibilitas dan keamanan BRT terhadap pemilihan BRT.

McFadden $R$ Square merupakan ukuran yang sama dengan ukuran $\mathrm{R}^{2}$ pada multiple regression yang didasarkan pada teknik estimasi likelihood dengan nilai maksimum kurang dari 1 (satu) sehingga sulit diinterpretasikan. McFadden $R$ Square untuk memastikan bahwa nilainya bervariasi dari 0 (nol) sampai 1 (satu). Hal ini dilakukan dengan cara membagi nilai McFadden $R^{2}$ dengan nilai maksimumnya. Dilihat dari output SPSS pada tabel 4.13, nilai McFadden $R$ Square diperoleh sebesar 0,7599 yang menunjukkan bahwa variabel Harga, Kenyamanan, keandaan, aksesibilitas dan keamanan BRT terhadap Pemilihan BRT adalah sebesar 75,99\% dan sisanya sebesar $14,01 \%$ dipengaruhi oleh variabel lain.

Hasil penelitian mendapatkan bahwa koefisien regresi positif diperoleh 
dari seluruh variabel independen yang diguanakan dalam penelitian ini yaitu variabel harga, kenyamanan, keandaan, aksesibilitas dan keamanan BRT terhadap Pemilihan BRT.

Dari hasil estimasi pada Tabel 3, dapat diubah menjadi model permilihan moda BRT di Kota Semarang, sebagai berikut.

$$
\begin{aligned}
\frac{P}{1-P}=- & 28,502+0,220 \text { HARGA }+0,306 \\
& \text { KENYAMANAN }+0,317 \\
& \text { KEANDALAN }+0,456 \\
& \text { AKSESIBILITAS }+0,481 \\
& \text { KEAMANAN .............(1) }
\end{aligned}
$$

Hasil tersebut dapat diinterpretasikan sebagai berikut :

1. Konstanta sebesar $-28,524$ menunjukkan angka negatif yang berarti bahwa dalam kondisi tidak dipengaruhi oleh persepsi harga, kenyamanan, keandaan, aksesibilitas dan keamanan BRT maka ada kecenderungan tidak ada keinginan memilih BRT.

2. Koefisien regresi variabel persepsi harga sebesar 0,220. Hal ini berarti bahwa persepsi yang lebih murah mengenai BRT akan memperbesar probabilitas pemilihan BRT.

3. Koefisien regresi variabel persepsi kenyamanan sebesar 0,306. Hal ini berarti bahwa persepsi yang lebih besar mengenai kenyamanan BRT akan memperbesar probabilitas pemilihan BRT.

4. Koefisien regresi variabel persepsi keandalan sebesar 0,317. Hal ini berarti bahwa persepsi yang lebih besar mengenai keandalan BRT akan memperbesar probabilitas pemilihan BRT.

5. Koefisien regresi variabel persepsi aksesibilitas sebesar 0,456. Hal ini berarti bahwa persepsi yang lebih besar mengenai aksesibilitas BRT akan memperbesar probabilitas pemilihan BRT.
6. Koefisien regresi variabel persepsi kenyamanan sebesar 0,481. Hal ini berarti bahwa persepsi yang lebih besar mengenai keamanan BRT akan memperbesar probabilitas pemilihan BRT

\section{Pengaruh Persepsi Harga Terhadap Pemilihan BRT}

Pengujian variabel persepsi harga mempunyai pengaruh positif terhadap pemilihan moda BRT. Hal ini menunjukkan bahwa persepsi mengenai harga BRT yang lebih murah akan meningkatkan pemilihan moda BRT tersebut. Demikian pula apabila persepsi mengenai harga relatif mahal probabilitas pemilihan BRT akan semakin rendah.

Persepsi yang lebih baik mengenai harga mencerminkan, konsumen menilai bahwa harga BRT sudah memiliki kesesuaian dengan daya beli konsumen. Selain itu persepsi positif juga menunjukkan bahwa harga tiket BRT sudah sesuai dengan manfaat dan nilai yang diperoleh. Kondisi kesesuaian tersebut menjadikan konsumen akan merasa bahwa BRT memiliki probabilitas penerimaan yang tinggi untuk dapat dibeli dan dibanding dengan moda lainnya. Hal ini berbeda dengan penelitian Lestari (2007) dijelaskan bahwa harga berpengaruh dan signifikan terhadap pemilihan moda transportasi.

\section{Pengaruh Persepsi Kenyamanan Terhadap Pemilihan BRT}

Berdasarkan pada persamaan,
persepsi kenyamanan mempunyai
pengaruh positif dan signifikan terhadap
Pemilihan BRT. Hal ini menunjukkan
bahwa persepsi mengenai kenyamaan
BRT yang lebih besar akan meningkatkan
probabilitas pemilihan BRT tersebut.
Demikian pula apabila persepsi mengenai
kenyamanan yang relatif kecil maka
probabilitas pemilihan BRT akan
semakin rendah. Persepsi yang lebih baik


mengenai kenyamanan mencerminkan bahwa konsumen menilai bahwa BRT sudah memiliki fasilitas yang nyaman dan sesuai dengan kebutuhan. Kenyamanan dari sebuah moda transportasi menjadi salah satu faktor yang dapat menjadi daya tarik bagi konsumen.

Dari hasil penelitian ini sesuai dengan penelitian yang dilakukan oleh Djakfar, dkk. (2010) bahwa variabel kenyamanan memiliki pengaruh positif dan signifikan pada taraf signifikan 5\% $(0,05)$ dengan tingkat signifikan sebesar 0,0095 . Penelitian ini sama dengan penelitian yang telah dilakukan oleh Lestari (2007) bahwa kenyamanan memiliki pengaruh positif dan signifikan terhadap pemilihan moda transportasi.

\section{Pengaruh Persepsi Keandalan Terhadap Pemilihan BRT}

Persepsi keandalan merupakan salah satu faktor pemilihan moda transportasi. Keandalan sendiri bisa dilihat dari beberapa dimensi misalnya keandalan dalam memberikan pelayanan, kepedulian petugas, ketepatan waktu, kesesuaian pelayanan yang dijanjikan dan ketapatan administrasi. Jika dilihat pada tabel 3 menurut responden tentang keandalan bahwa persepsi keandalan dinilai sangat tinggi.

Terlihat pada persamaan 3 keandalan memiliki pengaruh yang positif terhadap pemilihan moda transportasi umum BRT dan non-BRT dan signifikan pada taraf nyata alpha 5\% $(0,05)$ dengan nilai probalititas sebesar 0,0428 .

\section{Pengaruh Persepsi Aksesibilitas Terhadap Pemilihan BRT}

Merupakan konsep yang menggabungkan sistem pengaturan tata guna lahan secara geografis dengan sistem jaringan yang menghubungkannya. Menurut Black (1981), aksesibilitas adalah suatu ukuran kenyamanan atau kemudahan mengenai cara lokasi tata guna lahan berinteraksi satu sama lain dan mudah atau susahnya lokasi tersebut dicapai melalui sistem jaringan transportasi. Jika dilihat pada tabel 3 variabel aksesibilitas memiliki pengaruh yang positif dan signifikan pada taraf nyata $5 \%(0,05)$. Berbanding terbalik dengan penelitian sebelumnya oleh Djakfar, dkk. (2010) bahwa variabel aksesibilitas memiliki pengaruh positif dan tidak signifikan pada taraf signifikan $5 \%(0,05)$ dengan tingkat signifikan sebesar 0,236.

\section{Pengaruh Persepsi Keamanan terhadap pemilihan BRT}

Persepsi keamanan menjadi salah satu faktor yang dapat mempengaruhi pemilihan moda transportasi umum. Faktor aman, menunjukkan keamanan dari gangguan selama perjalanan yaitu rasa aman dari adanya tindakan kriminalitas, keselamatan dari risiko kecelakaan. Berdasarkan tabel 3 tentang persepsi keamanan menilai bahwa dipersepsikan sangat tinggi oleh responden yang memilih moda transportasi BRT. Pada persamaan menjelaskan bahwa keamanan memiliki hubungan yang positif dan signifikan pada taraf nyata $5 \%(0,05)$.

\section{PENUTUP}

Kesimpulan

Dari pembahasan yang telah diuraikan di muka serta berdasarkan data yang penulis peroleh dari penelitian sebagaimana yang telah dibahas dalam skripsi ini, maka dapat ditarik kesimpulan sebagai berikut :

1. Persepsi Harga berpengaruh positif dan tidak signifikan terhadap pemilihan BRT.

2. Persepsi Kenyamanan berpengaruh positif dan signifikan terhadap pemilihan moda BRT. Persepsi atas kenyamanan BRT lebih baik akan 
meningkatkan probabilitas pemilihan BRT.

3. Persepsi Keandalan berpengaruh positif dan signifikan terhadap pemilihan moda BRT. Persepsi atas keandalan BRT lebih baik akan meningkatkan probabilitas pemilihan BRT.

4. Persepsi aksesibilitas berpengaruh positif dan signifikan terhadap pemilihan moda BRT. Persepsi atas aksesibilitas BRT lebih baik akan meningkatkan probabilitas pemilihan BRT.

5. Persepsi keandalan berpengaruh positif dan signifikan terhadap pemilihan moda BRT. Persepsi atas keandalan BRT lebih baik akan meningkatkan probabilitas pemilihan BRT.

\section{Keterbatasan Penelitian}

Perlu diteruskan penelitian tentang permintaan konsumen dalam pemiilihan moda transportasi umum, karena transportasi umum merupakan kebutuhan yang penting bagi pengembangan kota besar. Akan lebih baik lagi jika variabel penelitian ditambah karena masih banyak faktor yang mempengaruhi pemilihan moda transportasi untuk masyarakat Kota Semarang khususnya.

\section{Saran}

Berdasarkan kesimpulan yang diperoleh dalam penelitian ini, maka diajukan saran-saran sebagai berikut:

1. Berdasarkan hasil penelitian, maka disarankan kepada pihak pengembang moda transportasi umum, apabila akan membangun koridor baru lagi perlu memperhatikan segi karakteristik pengguna moda transportasi umum dengan persepsi yang beragam karena responden yang menggunakan kendaraan umum lebih memilih untuk menggunakan moda transportasi BRT dibanding menggunakan transportasi non-BRT.

2. Faktor harga untuk transportasi umum BRT dan Non BRT menurut responden sudah dikategorikan murah. Apabila dinaikkan harganya tidak mengurangi minat untuk menggunakan layanan BRT, namun kualitas pelayanannya juga harus ditingkatkan.

3. Faktor kenyamanan untuk transportasi umum BRT dan Non BRT diperlukannya perawatan armadanya seperti kebersihan di dalam kendaraan, perbaikan AC untuk BRT, dan fasilitas lainnya.

4. Faktor keandalan untuk transportasi umum BRT dan Non BRT diperlukan peningkatan ketepatan waktu keberangkatan dan penambahan jumlah armada atau kendaraan.

5. Faktor Aksesibilitas untuk transportasi Umum BRT dan Non BRT diperlukan penambahan halte atau tempat menunggu dan penyesuaian antara trayek utama, ranting dan cabang agar saling terhubung

6. Faktor keamanan untuk transportasi umum BRT dan Non BRT diperlukannya peningkatan perilaku supir dalam berkendara dan keselamatan penumpang pada saat menggunakan transportasi umum.

\section{DAFTAR PUSTAKA}

Aidoo E.N., Agyemang W., Monkah J.E., \& Afukaar F. K. (2013). Passenger's Satisfaction With Public Bus Transport Services In Ghana: A Case Study Of Kumasi-Accra Route. Ghana: Theoretical and Empirical Researches in Urban Management. 8(2), 33-34. 
Aminuddin. (2008). Pola Operasi Angkutan Umum Perkotaan Ditinjau Dari Perspektif Perilaku Pengemudi. Bandung: Institut Teknologi Bandung.

Cole, S. (2005). Applied Transport Economics; Policy, Management \& Decision Making. United Kingdom: Kogan Page Limited.

Djakfar, L., Indriastuti, A.K., \& Nasution, A.S. (2010). Studi Karakteristik Dan Model Pemilihan Moda Angkutan Mahasiswa Menuju Kampus (Sepeda Motor Atau Angkutan Umum) Di Kota Malang. Jurusan Teknik Sipil Fakultas Teknik Universitas Brawijaya.

Gujarati, D.N. \& Potter, D.C. (2009). Basic Econometrics. Singapore: Mc Graw Hill.

Husna, R. (2016). Analisis Perilaku Konsumen Muslim dan Perilaku Expenditure Switching Konsumen Muslim Terhadap Konsumsi Kosmetik Berlabel Halal. Fakultas Ekonomika dan Bisnis. Universitas Diponegoro.

Ismail, R., Hafezi, M. H., Nor, R. M., \& Ambak, K. 2012. Passengers Preference and Satisfaction of Public Transport in Malaysia. Australian Journal of Basic and Applied Sciences.

Jou, R. C., \& Chen, T. Y. (2014). Factors Affecting Public Transportation, Car, Motorcycle Usage. Transportation Research Part A, 1.

Lestari, W. (2007). Pengaruh Status Sosial Ekonomi Terhadap Pemilihan Moda Transportasi Untuk Perjalanan Kerja (Studi Kasus Karyawan PT SSSWI Kabupaten Wonosobo). Tesis Magister Teknik Sipil Universitas Diponegoro.
Martini, N. P. R., \& Sudibia, I. K. (2013). Keputusan Melakukan Mobilitas Penduduk dan Dampaknya Terhadap Pendapatan Migran di Kota Denpasar. E-Jurnal Ekonomi Pembangunan Universitas Udayana, 2(2).

Nasution, M.N. (2004). Manajemen Transportasi. Jakarta: PT. Ghalia Indonesia.

Putra, T.K.A. (2013). Analisis Preferensi Masyarakat terhadap Bus Rapid Transit (BRT) Trans Semarang. Fakultas Ekonomika dan Bisnis. Universitas Diponegoro.

Trinandika, Y. dkk. (2013). Kualitas Pelayanan Bus Rapid Transit (BRT) Trans Semarang Terhadap Kepuasan Pelanggan (Koridor IV Cangkiran Bandara A. Yani). Fakultas Ekonomika dan Bisnis. Universitas Diponegoro.

Umar, H.B. (2009). Principal Component Analysis (PCA) dan aplikasinya dengan SPSS. Jurnal Kesehatan Masyarakat. 3(2), 97-101.

UU No. 22 tahun 2009 tentang Lalu Lintas dan Angkutan Jalan pasal 158 ayat 1 . 